\title{
Pengaruh Penyuntikan Ekstrak Kelenjar Hipofisa Ayam Broiler Terhadap Fertilitas, Daya Tetas Dan Survival Rate Ikan Mas (Cyprinus carpio L.)
}

\author{
Masrizul dan Azhar \\ Jurusan Produksi Ternak Fakultus Peternukan Universitas Andalus, Padang
}

\begin{abstract}
The objectives of this experiment were to studty the effect of chicken hypophyse gland extract for spowning of curp. Each twenty female of about $2950-3050 \mathrm{~g} / \mathrm{head}$ and $100 \mathrm{of}$ male carp of about $300-350 \mathrm{~g}$ body weigh/head were used in the experiments. Hypophyse gland extract were prepared from the hypophyse glands of hroiler chickens of about 40 days old. As treatments, the extract was injected in five different dases of $200,400,600$. 800 and $1000 \mathrm{mg} / \mathrm{kg}$ body wetght. Each dose was injected nice. The second injection was done after thours. Each treatment consisted of 4 replications as block. Parameter measured included: egg fertility, egg hatching nate and survival rate of larvae, water qualities (temperature, dissolved $\mathrm{O}_{2}$ free $\mathrm{CO}_{3} \mathrm{NH}_{3}$ content and $\mathrm{pH}$ ). Data were statistically analyzed by wariance analysis in randomized block design (RBD). Results indicated that injection of broiler's hypophyse gland extract gave highly significant ( $P<$ 0.01) effect on spawning egg fertility, egg hatching rate and survival rata of carp larvae of three days old. The optimal injection dose was found 582 mg brodter's hypophyse gland/kg carp body weight.
\end{abstract}

Key words: broilers' hypophysise gland, carp breeding-

\section{Pendahuluan}

Ikan mas (Cyprinus carpio Li) adalah merupakan salah satu jenis ikan air tawar yang sudah bisa dibudidayakan. Bila dibandingkan dengan jenis ikan air tawar lainnya, ikan mas memiliki beberapa keunggulan yaitu pertumbuharinya yang sangat cepat, mudah dipelihara, memiliki nilai gizi dan nilai ekonomis yang cukup tinggi.

Dalam usaha budidaya ikan mas, jaminan penyediaan benih yang berkualitas baik dan dengan jumlah yang cukup dan berkesinambungan merupakan faktor mutlak yang sangat menentukan keberhasilan usaha. Untuk meme- muhi hal tersebut, haruslah melalui pembenihan secara terkontrol yaitu dengan melakukan pemijahan secara buatan (induced breeding) yang diikuti dengan pembuahan buatan (artificial fertilization).

Dalam melakukan pembuahan buatan, teknik yang sering digunakan adalah teknik hipofisasi. Hipofisasi adalah merupakan usaha untuk merangsang ikan yang matang kelamin untuk ovulasi dan memijah melalui penyuntikan dengan ekstrak kelenjar hipofisa. Hardjamulia dan Atmawinata (1980) mengemukakan bahwa teknik hipotisasi pada ikan dilakukan dengan menggunakan hipofisa ikan, baik hipofisa ikan yang sejenis maupun yang tidak 
sejenis antara donor (ikan yang diambil hipofisanya) dan resipient (ikan yang disuntik).

Walaupun telah ditemukan teknik hipofisasa yang dapat memijahkan (mengawinkan) ikan setiap saat, namun para petani ikan lebih suka memijahkan ikan mas secara alami. Hal ini disebabkan karena pada teknik hipofisasi, para petani ikan harus mengorbankan ikan lain untuk dijadikan sebagai donor hipofisa dan ini merupakan kelemahan teknik hipofisasi. Untuk itu maka perlu dicobakan kelenjar hipofisa hewan lain diantaranya kelenjar hipofisa ayam broiler. Disamping murah, kelenjar hipofisa ayam broiler mudah sekali didapatkan, karena kelenjar hipofisa ayam broiler ini terbuang percuma sebagai limbah bersama tulang tengkorak kepala ayam di pasarpasar tempat pedagang memotong dan menjual ayam broiler.

Berdasarkan hal tersebut di atas, maka penulis tertarik melakukan suatu penelitian tentang penggunaan kelenjar hipofisa ayam broiler dalam teknik hipofisasi ikan mas (Cyprimus carpio L.).

Tujuan dari penelitian ini adalah untuk mengetahui hasil pemijahan (fertilitas telur, daya tetas telur dan sulvival rate larva ikan mas sampai umur 3 hari) ikan mas yang dipijahkan dengan teknik hipofisasi yang menggunakan kelenjar hipofisa ayam broiler. Dari hasil penelitian ini diharapkan akan dapat ditemukan dosis penyuntikan kelenjar hipofisa ayam broiler yang optimal untuk merangsang pemijahan induk ikan mas dengan menggunakan teknik hipofisasi.

\section{Metode Penelitian}

Penelitian ini dilakukan dari tanggal 22 Agustus sampai 25 Desember 2006, yaitu di Balai Benih lkan Kiambang Kecamatan 2 × 11 Enam Lingkung, Kabupaten Padang Pariaman, Propinsi Sumatera Barat.

Ikan uji yang digunakan dalam penelitian ini adalah 20 ekor ikan mas betina matang gonad dengan berat berkisar antara $2,950 \sim 3,050$ gram/ekor dan 100 ekor ikan mas jantan yang matang gonad dengan berat berkisar antara $300 \sim 350$ gram/ekor. Untuk kelenjar hipofisa digunakan kelenjar hipofisa ayam broiler yang diambil dari kepala ayam broiler berumur 40 hari.

Rancangan yang digunakan dalam penelitian ini adalah Rancangan Acak Kelompok (RAK), yang terdiri dari enam taraf perlakuan dan setiap taraf perlakuan terdiri atas empat kelompok yang berdasarkan kepada waktu pelaksanaan ulangan penelitian (Steel dan Torrie, 1989). Adapun perlakuan dalam penelitian ini adalah dosis penyuntikan kelenjar hipofisa ayam broiler yang terdiri dari lima taraf yaitu : $200 \mathrm{mg}\left(\mathrm{P}_{1}\right), 400 \mathrm{mg}\left(\mathrm{P}_{2}\right), 600$ $\mathrm{mg}\left(\mathrm{P}_{3}\right), 800 \mathrm{mg}\left(\mathrm{P}_{4}\right)$ dan $1.000 \mathrm{mg}$ $\left(\mathrm{P}_{5}\right)$ kelenjar hipofisa ayam boiler/kg ikan mas.

Penyuntikan ekstak kelenjar hipofisa ayam broiler ini dilakukan sebanyak dua kali, dimana penyuntikan pertama adalah sebanyak sepertiga dari dosis periakuan, dan setelah empat jam kemudian dilakukan pula penyuntikan ke dua yaitu sebanyak dua pertiga dosis perlakuan. Setelah itu induk ikan mas betina dibiarkan dalam bak pemijahan sampai terlihat tandatanda terjadinya ovulasi atau pemijahan. 
Peubah yang diamati dalam penelitian ini adalah fertilitas telur, daya tetas telur dan sulvival rate larva ikan mas umur 3 hari. Selain itu dilakukan pula pengukuran parameter kualitas air yang meliputi suhu, oksigen $\left(\mathrm{O}_{2}\right)$ terlarut, karbondioksida $\left(\mathrm{CO}_{2}\right)$ bebas, amoniak $\left(\mathrm{NH}_{3}\right)$ dan derajat keasaman $(\mathrm{pH})$.

Data hasil penelitian dianalisis dengan analisis ragam berdasarkan Rancangan Acak Kelompok (Steel dan Torrie, 1989). Uji lanjut dilakukan dengan uji wilayah berganda duncan, dan disamping itu dilakukan pula uji polinomial orthogonal (Sudjana, 1988) yaitu untuk menentukan dosis penyuntikan ekstrak kelenjar hipolisa ayam broiler yang optimal.

\section{Hasil Dan Pembahasan}

\section{Kualitas Air Media}

Kualitas air akan menentukan terhadap proses pemijahan ikan, hasil pengamatan kualitas air selama penelitian, baik dalam bak pemijahan, penetasan maupun dalam bak pemeliharaan larva berada dalam kualitas yang baik, sehingga diharapkan kualitas air ini tidak memberikan bias pada penelitian ini. Untuk lebih jelasnya parametar kualitas air selama penelitian dapat dilihat pada Tabel 1. Pada Tabel 1 terlihat bahwa keadaan kisaran parameter kualitas air selama penelitian masih memenuhi bersyaratan yang baik. Woynarovich dan Horvath (1980) mengemukakan kenaikan dan penurunan suhu air secara mendadak tidak lebih dari 6 ${ }^{\circ} \mathrm{C}$ tidak membahayakan kehidupan larva ikan. Kemudian Silvester dalam Wardoyo (1975) mengemukakan kandungan oksigen terlarut yang layak bagi kehidupan ikan tidak boleh kurang dari 4 ppm. Alabaster dan Lloyd (1980) menyatakan kandungan karbondioksida yang tidak berbahaya bagi kehidupan larva ikan adalah di bawah $10 \mathrm{ppm}$. Pescod (1973) menyatakan kandungan amoniak yang baik untuk kehidupan ikan adalah kurang dari 1 ppm. Sedangkan Boyd (1979) menyatakan derajat keasaman $(\mathrm{pH})$ yang baik atau ideal bagi kehidupan ikan berkisar antara $6,5-8,5$.

Tabel 1. Hasil Pengukuran Parameter Kualitas Air Media Pada Bak Pemijahan, Penetasan Dan Pemeliharaan Larva Ikan Mas Selama Penelitian

\begin{tabular}{clcc}
\hline No. & \multicolumn{1}{c}{ Parameter } & Satuan & Hasil Pengukuran \\
\hline 1 & $\mathrm{Suhu}$ & ${ }^{0} \mathrm{C}$ & $24,5-29,5$ \\
2 & Oksigen Terlarut $\left(\mathrm{O}_{2}\right)$ & $\mathrm{Ppm}$ & $5,23-6.19$ \\
3 & Karbon Dioksida $\left(\mathrm{CO}_{2}\right)$ & $\mathrm{Ppm}$ & $1,76-2,33$ \\
4 & Amoniak $\left(\mathrm{NH}_{3}\right)$ & Ppm & $0,008-0,128$ \\
5 & Derajat Keasaman $(\mathrm{pH})$ & Unit & $7,25-7,38$ \\
\hline
\end{tabular}


Tabel 2. Persentase Fertilitas Telur Ikan Mas Pada Masing-Masing Perlakuan Dan Kelompok.

\begin{tabular}{|c|c|c|c|c|c|}
\hline \multirow[b]{2}{*}{ Kelompok } & \multicolumn{5}{|c|}{ Perlakuan (mg kelenjar hipofisa ayam broile/kg ikan mas) } \\
\hline & $P_{1}(200)$ & $P_{2}(400)$ & $P_{3}(600)$ & $P_{4}(800)$ & $\begin{array}{c}P_{5}(1.000 \\
)\end{array}$ \\
\hline 1 & 70,46 & 84,65 & 89,82 & 84,37 & 67,26 \\
\hline 2 & 76,16 & 90,34 & 93,34 & 88,26 & 72,55 \\
\hline 3 & 72,87 & 86,91 & 90,72 & 84,53 & 65,94 \\
\hline 4 & 73,39 & 88,54 & 91,59 & 89,93 & 68,60 \\
\hline Jumlah & 292,88 & 350,44 & 365,47 & 347,09 & 274,35 \\
\hline Rataan & $73,22^{C}$ & $87,61^{\mathrm{ABD}}$ & $91,37^{A x}$ & $86,77^{\mathrm{Bb}}$ & $68,59^{\mathrm{D}}$ \\
\hline & $\begin{array}{l}\text { erskrip den } \\
01) \text {. }\end{array}$ & huruf besar y & berbeda me & ikan berbed: & gat nyata ( \\
\hline
\end{tabular}

\section{Fertilitas Telur}

Yang dimaksud dengan fertilitas telur dalam penelitian ini adalah merupakan kemampuan telur yang telah diovulasikan untuk dibuahi oleh sperma. Data hasil pengamatan fertilitas telur selama penelitian dapat dilihat pada Tabel 2 .

Pada Tabel 2 terlihat bahwa rataan persentase fertilitas telur ikan mas tertinggi terdapat pada perlakuan dengan penyuntikan 600 $\mathrm{mg}$ kelenjar hipofisa ayam broiler $/ \mathrm{kg}$ ikan mas $\left(P_{3}\right)$ yaitu 91,37\%. Sedangkan yang terendah terdapat pada perlakuan dengan penyuntikan $1.000 \mathrm{mg}$ kelenjar hipofisa ayam broiler/kg ikan mas $\left(P_{5}\right)$ yaitu 68,59 $\%$.

Hasil analisis ragam menunjukan bahwa penyuntikan kelenjar hipofisa ayam broiler dengan dosis yang berbeda memberikan pengaruh yang sangat nyata $(\mathrm{P}<0,01)$ terhadap persentase fertilitas telur ikan mas. Kemudian hasil uji lanjut wilayah berganda Duncan menunjukan pula bahwa persentase fertilitas telur ikan mas yang disuntik dengan $600 \mathrm{mg}$ kelenjar hipofisa ayam broiler $/ \mathrm{kg}$ berat ikan mas $\left(\mathrm{P}_{3}\right)$ sangat nyata $(\mathrm{P}<$ $0,01)$ lebih tinggi bila dibandingkan dengan ikan mas yang disuntik dengan $800 \mathrm{mg}\left(\mathrm{P}_{4}\right), 400 \mathrm{mg}\left(\mathrm{P}_{2}\right)$, $200 \mathrm{mg}\left(\mathrm{P}_{1}\right)$, dan $1.000 \mathrm{mg}\left(\mathrm{P}_{5}\right)$ kelenjar hipofisa ayam broiler/kg berat ikan mas.

Hasil uji polinomial orthogonal menunjukan bahwa hubungan antara dosis penyuntikan kelenjar hipofisa ayam broiler $(\mathrm{X})$ dengan persentase fertilitas telur ikan mas (Y) adalah kuadtratik dengan persamaan regresinya : $\hat{\mathrm{Y}}=48,4821+0,1497 \mathrm{X}$ - 1,2905. $10^{-4} \mathrm{X}^{2}$, untuk lebih jelasnya dapat dilihat pada Gambar 1.

Dari Gambar 1, terlihat bahwa semakin tinggi dosis penyuntikan kelenjar hipofisa ayam broiler (200 $\mathrm{mg}-600 \mathrm{mg}$ ), maka persentase fertilitas telur ikan mas akan semakin tinggi. Hal ini disebabkan karena semakin tingginya kandungan hormon LH (Luteinizing Hormon) di dalam darah ikan mas akibat dari penyuntikan kelenjar hipofisa ayam broiler. Dengan semakin tingginya hormon LH dalam darah ikan mas, menyebabkan semakin banyak pula telur yang mengalami proses pematangan sampai mencapai pematangan tahap akhir dan hal inilah yang menyebabkan semakin banyak pula telur yang dapat dibuahi oleh sperma, schingga meng- 


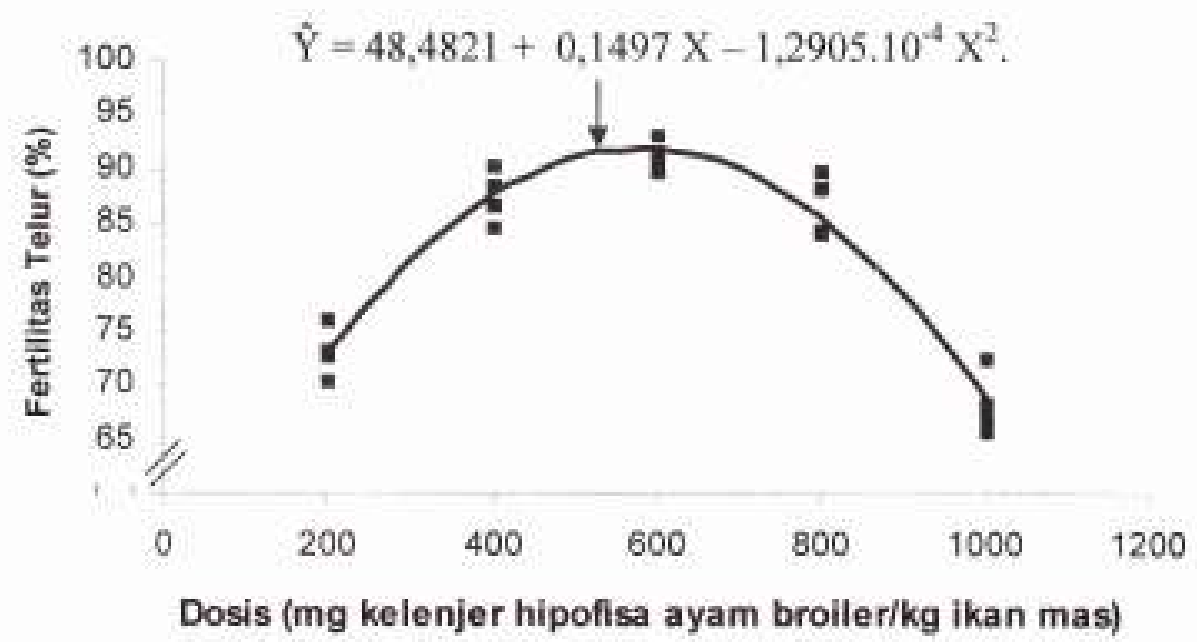

Gambar 1. Grafik hubungan antara dosis penyuntikan kelenjar hipofisa ayam broiler $(\mathrm{X})$ dengan persentase fertilitas telur ikan mas $(\mathrm{Y})$.

Tabel 3. Prosentase Daya Tetas Telur Ikan Mas Pada Masing-Masing Perlakuan Dan Kelompok.

\begin{tabular}{cccccc}
\hline \multirow{2}{*}{ Kelompok } & \multicolumn{5}{c}{ Perlakuan (mg kelenjar hipofisa ayam broile/kg ikan mas) } \\
\cline { 2 - 6 } & $\mathbf{P}_{\mathbf{1}} \mathbf{( 2 0 0 )}$ & $\mathbf{P}_{2}(\mathbf{4 0 0})$ & $\mathbf{P}_{3}(\mathbf{6 0 0})$ & $\mathbf{P}_{\mathbf{4}}(\mathbf{8 0 0})$ & $\mathbf{P}_{\mathbf{5}}(\mathbf{1 . 0 0 0}$ \\
& & & & & ) \\
\hline $\mathbf{1}$ & 62,43 & 75,78 & 82,34 & 73,30 & 58,53 \\
$\mathbf{2}$ & 70,53 & 84,43 & 90,03 & 81,43 & 66,29 \\
$\mathbf{3}$ & 65,58 & 79,51 & 85,64 & 77,86 & 60,36 \\
$\mathbf{4}$ & 66,06 & 82,78 & 88,42 & 81,94 & 64,44 \\
\hline Jumlah & $\mathbf{2 6 4 , 6 0}$ & $\mathbf{3 2 2 , 5 0}$ & $\mathbf{3 4 6 , 4 3}$ & $\mathbf{3 1 4 , 5 3}$ & $\mathbf{2 4 9 , 6 2}$ \\
\hline Rataan & $\mathbf{6 6 , 1 5}$ & $\mathbf{8 0 , 6 3}$ & $\mathbf{8 6 , 6 1 ^ { \mathrm { Aa } }}$ & $\mathbf{7 8 , 6 3}^{\mathrm{Bb}}$ & $\mathbf{6 2 , 4 1 ^ { \mathrm { D } }}$ \\
\hline
\end{tabular}

Keterangan : Superskrip dengan huruf besar yang berbeda menunjukan berbeda sangat nyata ( $P$ $<0,01)$, sedangkan superskrip dengan huruf kecil yang berbeda menunjukan berbeda nyata $(\mathrm{P}<0,05)$

akibatkan semakin tinggi persentase fertilitas telur ikan mas yang dihasilkan.

Dimana di dalam proses fertilisasi, hanya telur - telur yang telah mencapai pematangan tahap akhir atau Germinal Vesicle Break Down (GVBD) yang dapat dibuahi oleh sperma. Sehubungan dengan ini Sturkie (1976) menyatakan bahwa kelenjar hipofisa ayam broiler mengandung berbagai jenis hormon diantaranya adalah hormon LH (Luteinizing Hormon). Kemudian Lam (1982) dan Matty (1985) menambahkan bahwa hormon LH berfungsi merangsang proses ovulasi dan fertilisasi dalam pemijahan induk ikan betina. 
Berdasarkan persamaan regresi kuadratik diatas, dapat diketahui dosis penyuntikan kelenjar hipofisa ayam broiler yang optimal adalah $580 \mathrm{mg}$ kelenjar hipofisa ayam broiler/kg berat ikan mas dengan persentase fertilitas telur dugaan maximal $91,88 \%$. Jika dosis penyuntikan kelenjar hipofisa ayam broiler lebih tinggi dari dosis optimal $(580 \mathrm{mg})$, maka persentase fertilitas telur ikan mas menurun (Gambar 1). Hal ini diduga karena terjadinya over dosis yang menyebabkan terganggunya sistem kerja hormon dalam proses ovulasi tersebut, sehingga mengganggu terhadap proses pematangan telur dan sekaligus berpengaruh terhadap persentase fertilitas telur ikan mas. Menurut Bardach et. al., (1972) kelebihan dosis kelenjar hipofisa dalam teknik hipofisa dapat membuat ikan tidak memijah atau kembali sama seperti pada tingkat gonad belum matang (premature).

\section{Daya Tetas Telur}

Hasil pengamatan terhadap prosentase daya tetas telur ikan mas pada masing-masing perlakuan dan ulangan (kelompok) dapat dilihat pada Tabel 3.

Pada Tabel 3 terlihat bahwa rataan daya tetas telur ikan mas tertinggi terdapat pada perlakuan dengan penyuntikan $600 \mathrm{mg}$ kelenjar hipofisa ayam broiler/ $\mathrm{kg}$ ikan mas $\left(\mathrm{P}_{3}\right)$ yaitu 86,61\%. Sedangkan yang terendah terdapat pada perlakuan dengan penyuntikan $1.000 \mathrm{mg}$ kelenjar hipofisa ayam broiler/kg ikan mas $\left(\mathrm{P}_{5}\right)$ yaitu $62,41 \%$.

Hasil analisis ragam menunjukan bahwa penyuntikan kelenjar hipofisa ayam broiler dengan dosis yang berbeda memberikan pengaruh yang sangat nyata
$(\mathrm{P}<0,01)$ terhadap persentase daya tetas telur ikan mas. Kemudian hasil uji lanjut wilayah berganda Duncan menunjukan pula bahwa daya tetas telur ikan mas yang disuntik dengan $600 \mathrm{mg}$ kelenjar hipofisa ayam broiler/kg berat ikan mas $\left(P_{3}\right)$ sangat nyata $(P<0,01)$ lebih tinggi bila dibandingkan dengan ikan mas yang disuntik dengan $400 \mathrm{mg}\left(\mathrm{P}_{2}\right), 800 \mathrm{mg}$ $\left(\mathrm{P}_{4}\right), 200 \mathrm{mg}\left(\mathrm{P}_{1}\right)$ dan $1.000 \mathrm{mg}\left(\mathrm{P}_{5}\right)$ kelenjar hipofisa ayam broiler/ $\mathrm{kg}$ berat ikan mas.

Hasil uji polinomial orthogonal menunjukan bahwa hubungan antara dosis penyuntikan kelenjar hipofisa ayam broiler $(\mathrm{X})$ dengan persentase daya tetas telur ikan mas ( $\mathrm{Y}$ ) adalah kuadratik dengan persamaan regresinya: $\hat{\mathrm{Y}}=40,0479+0,1567 \mathrm{X}$ - 1.3458. $10^{-4} \mathrm{X}^{2}$, untuk lebih jelasnya dapat dilihat pada Gambar 2.

Dari Gambar 2, terlihat bahwa semakin tinggi dosis penyuntikan kelenjar hipofisa ayam broiler (200 mg sampai $600 \mathrm{mg}$ ), maka persentase daya tetas telur ikan mas akan semakin meningkat. Akan tetapi jika dosis penyuntikan kelenjar hipofisa ayam broiler ditingkatkan dari $600 \mathrm{mg}$ sampai $1.000 \mathrm{mg}$, maka persentase daya tetas telur ikan mas akan semakin menurun. Terjadinya peningkatan dan penurun daya tetas telur ini, akibat dari pada perlakuan yang diberikan dan hal ini berkaitan erat dengan terjadinya peningkatan dan penurunan persentase fertilitas telur yang telah dibahas sebelumnya. Sehubungan dengan ini Oyen et al. (1991), menyatakan persentase daya tetas telur selalu ditentukan oleh persentase fertilitas telur. dimana semakin tinggi persentase fertilitas telur maka semakin tinggi pula persentase daya tetas telur, kecuali kalau ada faktor lingkungan 
yang mempengaruhi seperti terjadi perubahan mendadak dari suhu, oksigen terlarut dan $\mathrm{pH}$.

Berdasarkan persamaan regresi kuadratik diatas, dapat diketahui dosis penyuntikan kelenjar hipofisa ayam broiler yang optimal adalah $582 \mathrm{mg}$ kelenjar hipofisa ayam broiler $/ \mathrm{kg}$ berat ikan mas dengan persentase daya tetas telur dugaan maximal $85,69 \%$. Persentase daya tetas telur dugaan ini lebih rendah jika dibandingkan dengan persentase fertilitas telur dugaan maximum $(91,88 \%)$, hal ini disebabkan karena tidak semua telur yang dibuahi akan menetas menjadi larva, karena pada saat proses penetasan telur, telur sangat rentan terhadap serangan jamur, hal ini pada saat penelitian terlihat adanya segumpal benang putih yang menyeliputi telur. Sedangkan menurut Hoffman (1967), menyatakan benang putih yang menyelimuti telur ikan pada saat proses penetasan adalah merupakan filamen dari jamur yang dapat merusak telur (telur jadi busuk).

\section{Sulvival Rate Larva}

Setelah dilakukan pemeliharaan larva hasil penetasan telur selama tiga hari pada setiap unit percobaan, didapatkan data persentase sutvival rate larva ikan mas umur tiga hari (SR-3 hari) seperti yang terdapat pada Tabel 4 .

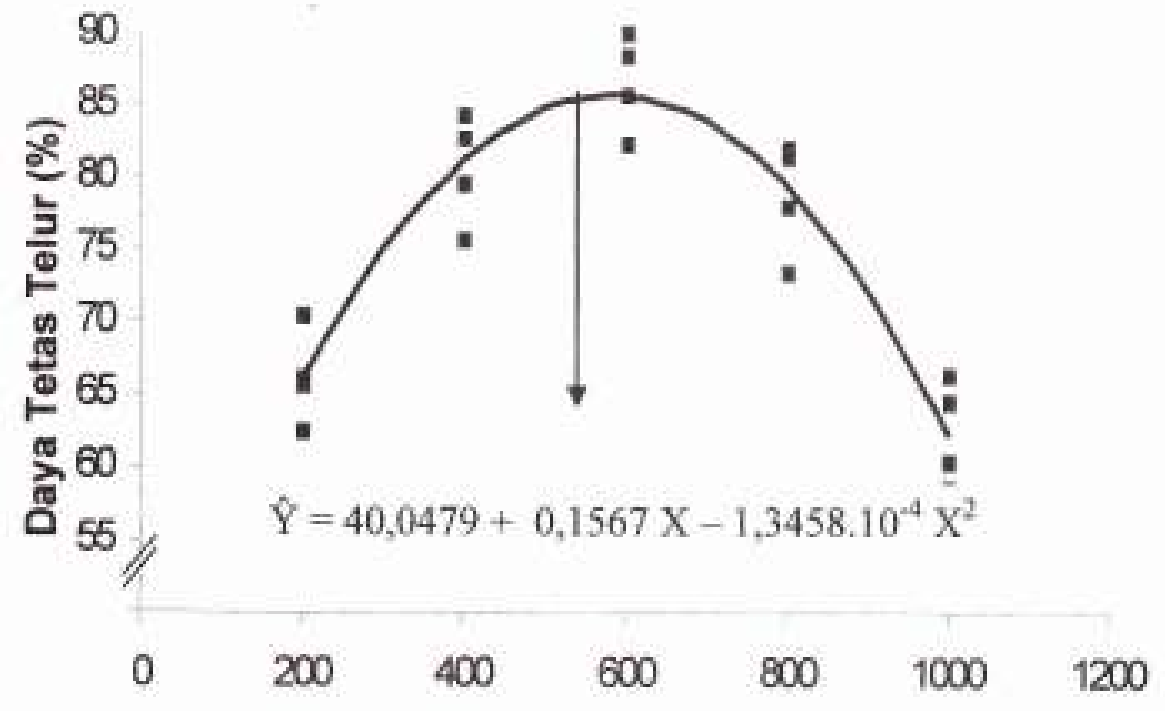

Dosis (mg kelenjer hipofisa ayam broller/kg ikan mas)

Gambar 2. Grafik hubungan antara dosis penyuntikan kelenjar hipofisa ayam broiler $(\mathrm{X})$ dengan prosentase daya tetas ikan mas $(\mathrm{Y})$. 
Tabel 4. Persentase Sulvival Rate Larva Ikan Mas Umur Tiga Hari (Sr-3 Hari) Pada Masing-Masing Perlakuan Dan Kelompok.

\begin{tabular}{|c|c|c|c|c|c|}
\hline \multirow[b]{2}{*}{ Kelompok } & \multicolumn{5}{|c|}{ Perlakuan (mg kelenjar hipofisa ayam broile/kg ikan mas) } \\
\hline & $P_{1}(\mathbf{2 0 0})$ & $P_{2}(400)$ & $P_{3}(600)$ & $\mathrm{P}_{4}(800)$ & $\begin{array}{c}P_{5}(1.000 \\
)\end{array}$ \\
\hline 1 & 81,80 & 90,00 & 90,80 & 84,40 & 81,80 \\
\hline 2 & 90,40 & 94,60 & 98,60 & 96,40 & 87,40 \\
\hline 3 & 87,20 & 89,80 & 92,80 & 89,00 & 78,20 \\
\hline 4 & 86,00 & 95,00 & 96,80 & 90,60 & 83,80 \\
\hline Jumlah & 345,40 & 369,40 & 379,00 & 360,40 & 331,20 \\
\hline Rataan & $86,35^{\mathrm{CDb}}$ & $92,35^{\mathrm{AB}}$ & $94,75^{\wedge}$ & $90,10^{\mathrm{BC}}$ & $82,80^{\text {De }}$ \\
\hline eterangan : & beda nyata ( $P$ & $\begin{array}{l}\text { huruf besar y } \\
\text { n superskrip } \\
0,05) \text {. }\end{array}$ & $\begin{array}{l}\text { berbeda me } \\
\text { ngan huruf }\end{array}$ & jukan berbedz & ngat nyata (1) \\
\hline
\end{tabular}

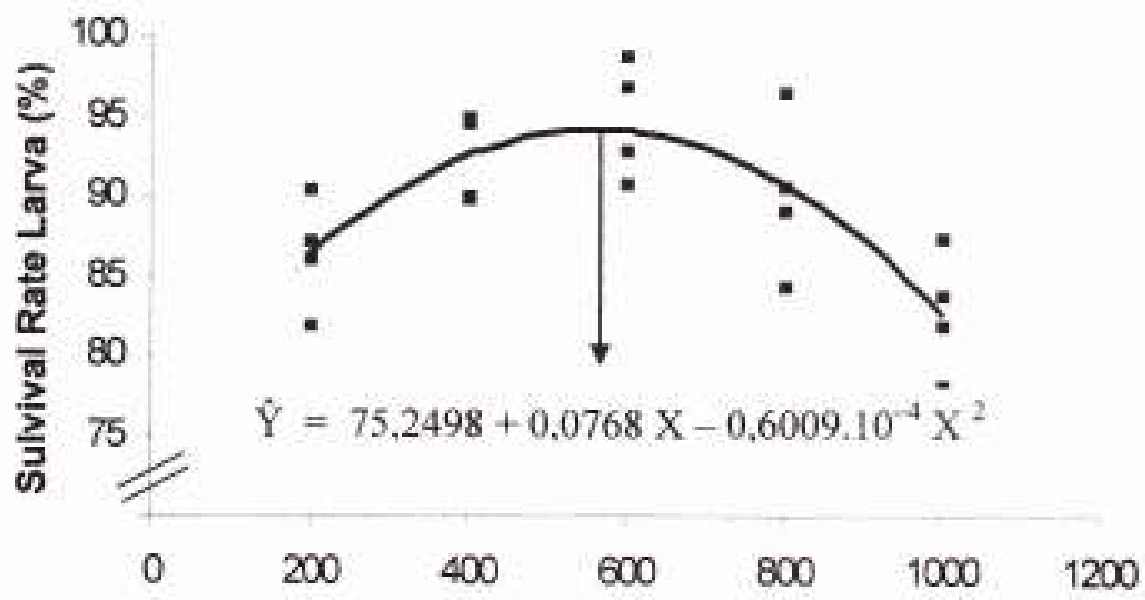

Dosis (mg kelenjer hipofisa ayam broiler/kg ikan mas)

Gambar 3. Grafik hubungan antara dosis penyuntikan kelenjar hipofisa ayam broiler $(\mathrm{X})$ dengan persentase sulvival rate larva ikan mas $(\mathrm{Y})$.

Pada Tabel 4 terlihat bahwa rataan persentase sulvival rate larva ikan mas tertinggi terdapat pada perlakuan dengan penyuntikan 600 $\mathrm{mg}$ kelenjar hipofisa ayam broiler $/ \mathrm{kg}$ ikan mas ( $\left.P_{3}\right)$ yaitu $94,75 \%$. Sedangkan yang terendah terdapat pada perlakuan dengan penyuntikan $1.000 \mathrm{mg}$ kelenjar hipofisa ayam broiler $/ \mathrm{kg}$ ikan mas $\left(\mathrm{P}_{5}\right)$ yaitu 82,80 $\%$.

Kemudian hasil uji lanjut wilayah berganda Duncan menunjukan pula bahwa sulvival rate larva ikan mas yang disuntik dengan $600 \mathrm{mg}$ kelenjar hipofisa ayam broiler $/ \mathrm{kg}$ berat ikan mas $\left(\mathrm{P}_{3}\right)$ sangat nyata ( $\mathrm{P}<0,01$ ) lebih tinggi bila dibandingkan dengan ikan mas yang disuntik dengan $400 \mathrm{mg}\left(\mathrm{P}_{2}\right), 800 \mathrm{mg}$ $\left(\mathrm{P}_{4}\right), 200 \mathrm{mg}\left(\mathrm{P}_{1}\right)$, dan $1.000 \mathrm{mg}\left(\mathrm{P}_{5}\right)$ kelenjar hipofisa ayam broiler $/ \mathrm{kg}$ berat ikan mas.

Hasil uji polinomial orthogonal menunjukan bahwa hubungan antara dosis penyuntikan kelenjar hipofisa ayam broiler ( $\mathrm{Y}$ ) dengan 
persentase sulvival rate larva ikan mas umur tiga hari $(\mathrm{X})$ adalah kuadratik dengan persamaan regresinya : $\dot{\gamma}=75,2498+0,0768$ $\mathrm{X}-0,6009 \cdot 10^{-4} \mathrm{X}^{2}$, untuk lebih jelasnya dapat dilihat pada Gambar 3.

Dari grafik pada Gambar 3, terlihat bahwa semakin tinggi dosis penyuntikan kelenjar hipofisa ayam broiler (200 mg sampai $600 \mathrm{mg}$ ), maka porsentase sulvival rate larva ikan mas akan semakin meningkat. $\mathrm{Hal}$ ini disebabkan karena semakin tingginya kandungan hormon $\mathrm{LH}$ (Luteinizing Hormon) di dalam darah ikan mas akibat dari penyuntikan kelenjar hipofisa ayam broiler, dan ini menyebabkan semakin banyak jumlah telur yang mengalami proses pematangan sampai mencapai pematangan tahap akhir. Apabila semakin banyak telur yang matang dengan kualitas yang sempurna, menyebabkan proses perkembangan embrio didalam telur akan lebih baik dan hal ini akan menghasilkan larva yang lebih baik pula kualitasnya yaitu larva yang mempunyai kemampuan hidup lebih tinggi, dan inilah yang menyebabkan sulvival rate larva ikan mas semakin tinggi.

Berdasarkan persamaan regresi kuadratik diatas, dapat diketahui dosis penyuntikan kelenjar hipofisi ayam broiler yang optimal adalah $639 \mathrm{mg}$ kelenjar hipofisa ayam broiler/kg berat ikan mas dengan persentase sulvival rate larva dugaan maximal $99.78 \%$. Jika dosis penyuntikan kelenjar hipofisa ayam broiler lebih tinggi dari dosis optimal (639 mg), maka persentase sulvival rate larva ikan mas menurun (Gambar 3). Hal ini diduga karena terjadinya over dosis yang menyebabkan terganggunya sistem kerja hormon dalam proses pematangan telur dan sekaligus berpengaruh terhadap persentase sulvival rate larva ikan mas.

\section{Kesimpulan Dan Saran}

\section{Kesimpulan}

Dari hasil penelitian yang telah dijelaskan di atas, maka dapat ditarik kesimpulan sebagai berikut :

1. Penyuntikan ekstrak kelenjar hipofisa ayam broiler dapat meningkatkan persentase fertilitas telur, daya tetas telur dan sulvival rate larva ikan mas.

2. Dosis penggunaan atau penyuntikasn kelenjar hipofisa ayam broiler yang optimal adalah $582 \mathrm{mg}$ kelenjar hipofisa ayam broiler/kg ikan mas, karena pada dosis ini akan memberikan persentase fertilitas telur, daya tetas telur dan sulvival rate larva ikan mas yang tertinggi.

\section{Saran}

Berdasarkan hasil penelitian yang telah dilakukan, maka dapat dikemukakan beberapa saran sebagai berikut :

1. Dalam melakukan pemijahan ikan mas secara hipofisasi menggunakan ekstrak kelenjer hipofisa ayam broiler sebaiknya digunakan dosis $582 \mathrm{mg}$ kelenjar hipofisa ayam broiler $/ \mathrm{kg}$ ikan mas.

2. Perlu penelitian lebih lanjut tentang penggunaan ekstrak kelenjer hipofisa ayam broiler dalam merangsang pemijahan ikan-ikan air tawar dan laut 
dari jenis-jenis ikan budidaya ekonomis lainnya.

\section{Daftar Pustaka}

Alabaster dan Lloyd (1980), Water Quality for Fresh Water Fish. FAO United Nations, London

Bardach, J.E., J.H. Ritner and W.O. Mc Larney. 1972. Aquaculture the Farming and Husbandry of Fresh Water and Marine Organism. John Wiley and Sons, New York.

Boyd, C. E., 1979, Water Quality in Warmwater Fish Ponds. Crafmaster Printers Inc. Opelica - Alabama.

Hardjamulia, A dan S. Atmawinata. 1980. Pembiakan dengan Teknik Hipofisasi Ikan Eksotik : Mola (Hyphothalmichthys molitrix) dan Koan (Ctenopharyngodon idella Val.). Pewarta LPPD. Bogor : Hal $1-5$.

Hoffman, G. L., 1967, Parasites of North American Fresh Water Fishes. University of Califomia Press, Berkeley.

Lam, T.J. 1982. Applications of Endocrinology to Fish Culture. Can. J. Fish. Aquat. Sci, $39: 111-137$.

Matty, A.J. 1985. Fish Endocrinology. Croom Helm and Timber Press, London - Sydney Portland-Oregon.
Oyen, F. G., L. E. C. M. M. Campr and E. S. W. Bongo, 1991. Effects of Acid Stress an The Embryonic Development of The Common Carp (Cyprinus carpio L.). $\mathrm{J}$ Aquat. Texicology, 19:1 12.

Pescod, M. B., (1973), Investigation of Retional Effluents and Stream Standard for Tropical Countries U. S. Army Research and Development Group. Far East. Report No. PE - 476 - 1, San Prancisco

Steel, R.G.D., dan J.A. Torrie. 1989. Prinsip dan Prosedur Statistika Suatu Pendekatan Biometrik. PT Gramedia, Jakarta.

Sturkie, P.D. 1976. Avian Physiology. Third Edition. Springer - Verlag, New York-Heidelberg-Berlin.

Sudjana. 1988. Disain dan Analisis Eksperimen. Tarsito, Bandung.

Wardoyo, S. T. H., (1975), Pengolahan Kualitas air. Proyek Peningkatan Mutu Perguruan Tinggi IPB, Bogor.

Woynarovich, E and I. Horvath, 1980. The Artificial Propagation of Warm Water Fin Fishes. A Manual For Extention. FAO, Fish. Teach. Pep, 201 ; $1-183$. 
Alamat korespondensi: Ir. Masrizal, MSi

Jurusan Produksi Ternak, Fakultas Petemakan

Universitas Andalas, Kampus Limau Manis, Padang

Telp. 0751-74208 Fax: 0751-71464

Diterima: 8 April 2007, Disetujui: 18 Mei 2007 